\author{
Abstracta Iranica \\ Abstracta Iranica Revue bibliographique pour le domaine irano-aryen \\ Volume 42-43 | 2021 \\ Comptes rendus des publications de 2019-2020
}

\title{
Sabir Badalkhan, Gian Pietro Basello, Matteo De Chiara (eds.). Iranian studies in honour of Adriano V. Rossi
}

Agnes Korn

\section{(2) OpenEdition Journals}

Electronic version

URL: https://journals.openedition.org/abstractairanica/52973

DOI: 10.4000/abstractairanica.52973

ISSN: 1961-960X

Publisher:

CNRS (UMR 7528 Mondes iraniens et indiens), Éditions de l'IFRI

\section{Electronic reference}

Agnes Korn, "Sabir Badalkhan, Gian Pietro Basello, Matteo De Chiara (eds.). Iranian studies in honour of Adriano V. Rossi", Abstracta Iranica [Online], Volume 42-43 | 2021, document 2, Online since 30

December 2021, connection on 16 December 2022. URL: http://journals.openedition.org/ abstractairanica/52973 ; DOI: https://doi.org/10.4000/abstractairanica.52973

This text was automatically generated on 16 December 2022 .

All rights reserved 


\section{Sabir Badalkhan, Gian Pietro Basello, Matteo De Chiara (eds.). Iranian studies in honour of Adriano $V$. Rossi}

Agnes Korn

\section{REFERENCES}

Sabir Badalkhan, Gian Pietro Basello, Matteo De Chiara (eds.). Iranian studies in honour of Adriano V. Rossi. Naples: UniorPress, 2019, XLII+1046 p. + LV planches (Università degli studi di Napoli "L'Orientale", Dipartimento Asia, Africa e Mediterraneo, Series minor LXXXVII), 2 vol.

1 This monumental work in two volumes is a tribute to Adriano Rossi, professor emeritus of Iranian Studies at the Università degli Studi di Napoli L'Orientale. (The de facto publication was considerable delayed by the pandemic.) The scope of the 61 articles aptly reflects his broad interests; most are in English, some in Italian (14), French (five) and German (two), arranged in alphabetic order of author.

2 As readers might expect, the vast majority of articles deal with Iranian languages and cultures, their literature and history. In chronological order, the following fields are covered:

Old Iranian and the Median and Achaemenid empires: Pierfranceso Callieri (cf. le compte rendu dans ce même numéro d'AbstIr), Julien Cuny, Julian Degen, Robert Rollinger, Ela Filippone, Bruno Genito, Jean Kellens, Gilbert Lazard, Romolo Loreto, Antonio Panaino, Flavia Pompeo, Enrico Raffaelli, Hassan Rahsaz, Céline Redard, Velizar Sadovski, Rüdiger Schmitt, Martin Schwartz;

Middle Iranian languages and cultures: Maria Carmela Benvenuto, Carlo Cereti, Iris Colditz, Simone Cristoforetti, Philippe Gignoux, Frantz Grenet, Claudia Leurini, Pavel 
Lurje, Mauro Maggi, Marco Mancini, Enrico Morano, Andrea Piras, Hassan Rezai Baghbidi, Shaul Shaked, Nicholas Sims-Williams ;

5 Modern Iranian:

6 - Western Iranian linguistics: Garnik Asatrian ;

7 - Persian and its varieties: Antonella Muratgia, Stefano Pellò, Antonia Soriente, Roberto Tottoli, Amir Zeyghami;

8 - Balochi and the Baloch: Sabir Badalkhan, Vahe Boyajian, Carina Jahani, Agnes Korn, Maryam Nourzaei, Giorgio Rota, Brian Spooner;

9 - Kurdish, the Kurds and the Yezidis: Salman Aliyari Babolghani, Viktoria Arakelova, Sara Belelli;

10 - Pashto: Matteo De Chiara, Roberto Micheli \& Luca Maria Olivieri.

11 There are also articles on neighbouring topics such as Indo-European studies (Franco Crevatin), archaeology of neighbouring regions (Roberto Dan, Maria Vittoria Fontana), Indology (Francesco Sferra), Armenian (Giancarlo Schirru), Byzantine literature (Gaga Shurgaia), Pontic inscriptions (Paolo Ognibene), and about scientific cooperation (Alireza Askari Chaverdi).

12 Equally wide-ranging are the perspectives adopted. A large number deal with linguistics in the largest sense (including synchronic and diachronic descriptions, etymology, onomastics), philology, manuscript studies, numismatics and onomastics. Likewise represented are archaeology, history and religious studies. Many articles highlight contact of languages and cultures within and beyond the Iranian sphere.

The work is introduced by foreword by the rector of the Orientale and the director of the department, an editors' preface and a survey by Bruno Genito about Adriano Rossi's time at the Orientale, followed by a bibliography of his numerous books and articles.

\section{AUTHORS}

\section{AGNES KORN}

CNRS, CeRMI, Paris 